\title{
Wheat-rye chromosome translocations involving small terminal and intercalary rye chromosome segments in the Portuguese wheat landrace Barbela
}

\author{
CARLOS RIBEIRO-CARVALHO + , HENRIQUE GUEDES-PINTO†, GILL HARRISON $\ddagger$ \& \\ JOHN S. HESLOP-HARRISON* $\ddagger$ \\ †Department of Genetics and Biotechnology, University of Trás-os-Montes and Alto Douro, 5000 Vila Real, Portugal \\ and $¥$ Karyobiology Group, John Innes Centre, Colney Lane, Norwich NR4 7UH, U.K.
}

The old Portuguese wheat landrace aggregate, known as Barbela, shows good productivity under low fertility conditions often associated with acid soils. Using genomic in situ hybridization with rye DNA, we were able to show that Barbela wheat lines contain small, spontaneously occurring, rye chromosome segments representing up to 5 per cent of a chromosome. Two independent accessions were studied which included terminal rye segments, and a further accession had one chromosome pair with a terminal segment and a second pair with an intercalary chromosome segment ( 3.5 per cent) of rye origin. Small alien chromosome segments are valuable in cereal breeding for transfer of useful characteristics into wheat without deleterious characteristics from the alien. These results show that such translocations may occur spontaneously and be of such high agronomic value that they are selected by farmers as landraces.

Keywords: biodiversity, in situ hybridization, landraces, plant breeding, rye, wheat.

\section{Introduction}

'Barbela' wheat (Triticum aestivum L. em Thell.) is an aggregate of old Portuguese landraces that has been discussed in the literature for more than a century (Lapa, 1865; Coutinho, 1884). The Barbela wheat population is variable and several morphological variants (erect, semi-erect and prostrate) are recognized, as well as a subrace with a characteristic large kernel, Barbela 'Grosso' or Tick Barbela (Vasconcelos, 1933; Monteiro, 1935). Barbela landraces show impressively wide adaptation to different environments. The landrace produced a worthwhile crop in low fertility conditions, often associated with acid soils-where it was only exceeded in yield by the regional rye populations-as well as in good fertile situations, although it often lodged (Guedes-Pinto et al., 1982; Bernard \& Guedes-Pinto, 1983). In the 1930 s, Barbela was the most cultivated wheat in

*Correspondence. E-mail: pat.heslop-harrison@bbsrc.ac.uk
Portugal (Monteiro, 1935; Castilho, 1954) showing winter hardiness in the northern, inner region and drought tolerance in the semi-arid and hot regions of the south. Now Barbela is out of the national catalogue of varieties but a programme to recover and characterize the subraces is being undertaken at the University of Trás-os-Montes and Alto Douro (UTAD).

Analysis of the genotype $\times$ environment interaction for agronomic data (Guedes-Pinto et al., 1982; Bernard \& Guedes-Pinto, 1983) shows that Barbela has a pattern like the regional rye populations. The similarity could be a response of two different species submitted to the same edaphoclimatic selection pressure genetically evolving similar adaptations (Marchenay \& Lagarde, 1987), or indicate that there is spontaneous introgression of rye germplasm into the wheat. In particular, its agronomic behaviour and aluminium tolerance studies in nutritive solution suggested that Barbela lines could carry a rye chromosomal translocation (Silva et al., 1991), and the fact that Barbela is frequently culti- 
vated with regional ryes, gives the opportunity for introgression.

Genomic in situ hybridization is a sensitive and accurate method that has been used to identify various alien chromosomes and chromosome segments in wheat (Schwarzacher et al., 1992). In particular the method is effective in identifying rye chromosome arms in wheat (Heslop-Harrison et al., 1991). Because of the unknown number, size and genetic composition of rye segments potentially present in the landrace, in situ hybridization was considered to be an efficient method to search for rye chromatin introgression, in preference to methods using molecular markers that would need many tests per line. Results from in situ hybridization can be informative about the size and chromosome location of any rye chromosomes or chromosome segments detected. In this study we searched for rye segments in the Barbela chromosomes using genomic in situ hybridization with rye DNA as a probe and $18 \mathrm{~S}-25 \mathrm{~S}$ rDNA as a second probe to assist chromosome identification.

\section{Materials and methods}

\section{Plant material}

Lines for screening by in situ hybridization were selected by their agronomic behaviour from one hundred lines each coming from a single spike collected from separate fields or localities in the northern, inner region of Portugal under 'Project Barbela' (PDRITM no. 2; Fig. 1). Seeds used in the investigation here were from the second generation after collection. Code numbers of lines are given in the results (in the format: individual-ear-code/collection-locality-code; collection locations are shown in Fig. 1 and detailed locality codes are available from Project Barbela, Department of Genetics and Biotechnology, UTAD). In each experiment, a triticale (cv. Lasko), rye (cv. Halo) or wheat variety carrying a $1 \mathrm{~B}-1 \mathrm{R}$ translocation (cv. Beaver) was used as a control for the in situ hybridization. Secale cereale L. (rye) cv. Petkus was used for probe preparation.

\section{Preparation of metaphases for in situ hybridization}

The seeds were germinated in distilled water on filter paper in Petri dishes at $25^{\circ} \mathrm{C}$. When the roottips were one or $2 \mathrm{~cm}$ long, they were excised and transferred to ice water at $0^{\circ} \mathrm{C}$ for $24 \mathrm{~h}$ and finally fixed in 3:1 (v/v) 100 per cent ethanol:acetic acid. Root-tip spread preparations were made as described by Schwarzacher et al. (1994) and slides pretreated with RNase $(100 \mu \mathrm{g} / \mathrm{mL})$ for one hour at $37^{\circ} \mathrm{C}$. The method was optimized to give extended, prometaphase-like chromosomes, rather than highly condensed metaphase chromosomes so that the size and location of any rye chromosome segments detected in the Barbela lines could be measured with high resolution.

\section{Probe and blocking DNA preparation}

Total genomic DNA from rye was isolated using standard methods (Sambrook et al., 1990), sonicated

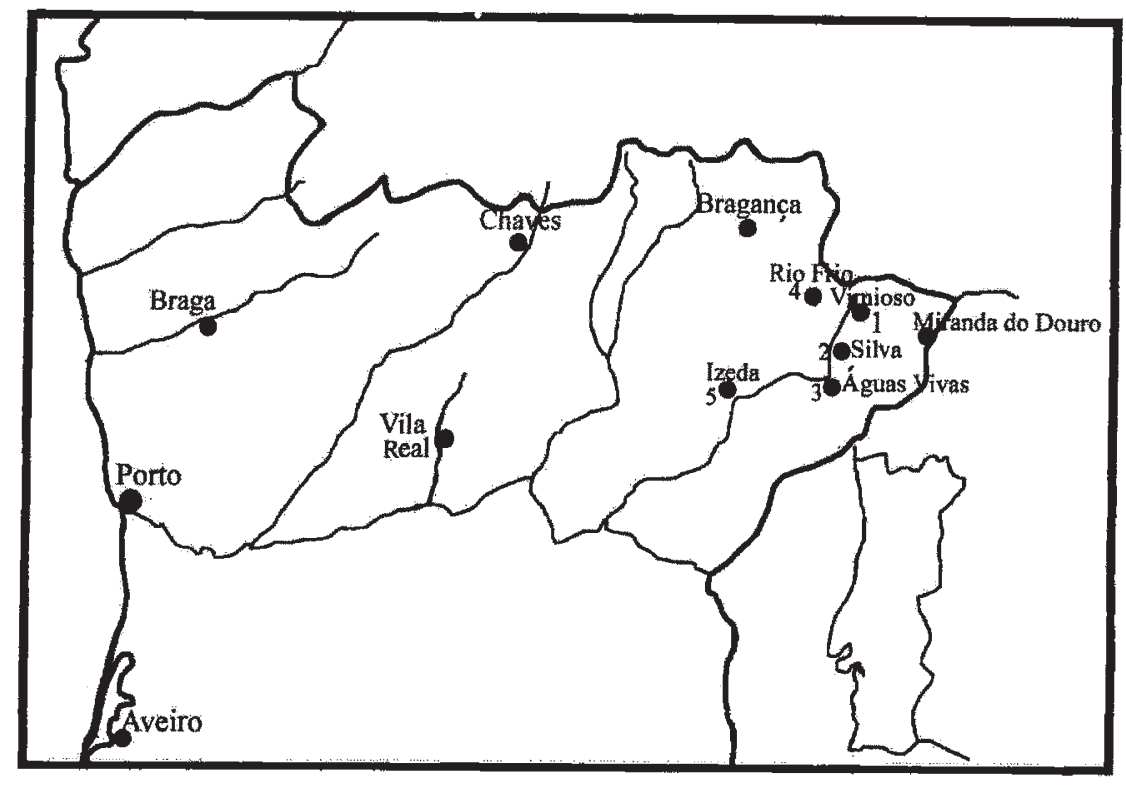

Fig. 1 A map of the north-east of Portugal showing the origin of the Barbela wheat lines used for analysis. 1, Line 34/66, Pinedo, VimiosoBragança; 2, 56/92, Vale da Carvalha, Silva-Miranda do Douro; 3, 16/95, Agual Vivas, Miranda do Douro; 4 , 39/114, Rio Frio-Bragança; 5, 38/119, Izeda-Bragança. 
to produce $10-12 \mathrm{~kb}$ fragments and labelled with digoxigenin-11-dUTP (Boehringer) by nick translation for use as a probe for in situ hybridization. Total genomic DNA from $T$. aestivum cv. Chinese Spring was fragmented to pieces $50-100$ bp long by autoclaving and used as blocking DNA (HeslopHarrison et al., 1988, 1990; Anamthawat-Jónsson et al., 1990).

The ribosomal rDNA sequence pTa71 contains a $9 \mathrm{~kb}$ EcoRI fragment of rDNA isolated from wheat T. aestivum L. em. Thell. (Gerlach \& Bedbrook, 1979) recloned into pUC19; it contains coding sequences for the $18 \mathrm{~S}, 5.8 \mathrm{~S}$ and $25 \mathrm{~S}$ rRNA genes and the intergenic spacer sequences (the rDNA, located at the nucleolar organizing regions, NORs, on the chromosomes). pTa71 was labelled with tetramethyl rhodamine isothiocyanate (TRITC)coupled dUTP (Amersham, Fluorored) by nick translation.

In situ hybridization and probe detection protocols followed Schwarzacher et al. (1994) with minor modifications. The probe concentrations (ng/slide) used in the hybridization mixture were: $75 \mathrm{ng}$ of total genomic DNA from rye, $75 \mathrm{ng}$ of pTa71 and blocking DNA at 35 times the amount of genomic probe DNA. The hybridization mixture also contained 50 per cent formamide, $1 \times \mathrm{SSC}$ $(20 \times$ stock: $3 \mathrm{M} \mathrm{NaCl}, 0.3 \mathrm{M} \mathrm{Na}$ citrate), 20 per cent (w/v) dextran sulphate, 3.75 per cent salmon sperm DNA and 0.25 per cent (w/v) sodium dodecyl sulphate (SDS). The hybridization mixture was denatured at $70^{\circ} \mathrm{C}$ for $10 \mathrm{~min}$, chilled on ice for $5 \mathrm{~min}$ and $40 \mu \mathrm{L}$ was applied to the chromosome preparation. After covering with a plastic coverslip, slides were denatured at $70^{\circ} \mathrm{C}$ for $5 \mathrm{~min}$ and hybridization was carried out overnight at $37^{\circ} \mathrm{C}$ in a humid chamber (Heslop-Harrison et al., 1991), followed by stringent washes in 20 per cent $(\mathrm{v} / \mathrm{v})$ formamide in $0.1 \times \mathrm{SSC}$ at $42^{\circ} \mathrm{C}$ for $10 \mathrm{~min}$. Final stringency was typically $80-85$ per cent, based on the formula of Meinkoth \& Wahl (1984) for DNA hybrids of more than 50 nucleotides in solution, where $T_{\mathrm{m}}=(0.41(\%$ GC) $-500 / n-0.61$ (\% formamide $+16.6 \log \mathrm{I}+81.5)^{\circ} \mathrm{C}$ ( $T_{\mathrm{m}}=$ dissociation temperature; $\mathrm{I}=$ ionic strength, $\mathrm{mol} / \mathrm{L} ; \mathrm{GC}=$ base composition, taken as 55 per cent for cereals; and $n=$ number of nucleotides in the probe). Experimental modulation of stringent wash conditions following in situ hybridization to chromosome preparations indicates that calculated hybridization stringency is correct (Schmidt \& Heslop-Harrison, 1996).

For detection of sites of probe hybridization, we used sheep anti-digoxigenin conjugated to fluorescein (anti-digoxigenin-FITC; Boehringer) for digox- igenin-labelled probes and streptavidin-Cy3 (Sigma) for the biotin-labelled probes. Slides were transferred into detection buffer $(4 \times$ SSC, 0.2 per cent $(\mathrm{v} / \mathrm{v})$ Tween-20) for $5 \mathrm{~min}$, treated with 5 per cent $(\mathrm{w} / \mathrm{v})$ bovine serum albumin (BSA) in detection buffer for $5 \mathrm{~min}$, and then incubated in $5 \mathrm{mg} \mathrm{mL}^{-1}$ CY3-labelled streptavidin and $20 \mathrm{mg} \mathrm{mL}^{-1}$ antidigoxigenin-fluorescein in detection buffer containing 5 per cent $(\mathrm{w} / \mathrm{v}) \mathrm{BSA}$ for $1 \mathrm{~h}$ at $37^{\circ} \mathrm{C}$. After incubation the slides were washed in detection buffer three times, $8 \mathrm{~min}$ each, at $37^{\circ} \mathrm{C}$. Chromosomes were counterstained with $4^{\prime}-6{ }^{\prime}$ diamidino2-phenylindole (DAPI, $4 \mathrm{mg} \mathrm{mL}^{-1}$ ). Slides were mounted in Citifluor-Glycerol and analysed on an epifluorescence Leica Aristoplan microscope with appropriate filters.

Photographs were taken with appropriate epifluorescence filters on Fuji Colour 400 Super G colour negative film and digitized using the Kodak Photo $C D$ system. Prints were made using Adobe Photoshop with contrast optimization applied equally to the whole image, and cropping or overlaying as appropriate.

\section{Results}

Genomic in situ hybridization with rye DNA as a probe was able to detect rye chromosome segments in a wheat background (Figs 2-6).

\section{Controls:triticale, 1B-1R wheats, rye}

In situ hybridization to triticale, using the same labelled batches of genomic rye DNA probe as for the Barbela lines, revealed the 14 chromosomes of rye origin by their bright fluorescence, whereas other chromosome arms, of wheat origin, showed only a very weak signal (Fig. 2). DAPI staining of chromosomes from rye also revealed bright terminal bands of heterochromatin, whereas in situ hybridization with the same genomic rye probe labelled chromosomes uniformly brightly, with a similar hybridization strength to the terminal regions and the NOR. Careful inspection of prints where the rye chromosomes were greatly overexposed during photography showed some wheat-origin chromosome arms where the labelling level was variable but slightly heavier, and gaps where no label at all was detected. With some batches of probes, the rRNA genes at the major nucleolar organizer regions of wheat origin were labelled and visible as bands; this also occurred on the Barbela metaphases (cf. Figs 3 and 4). Apart from these rDNA sites, no labelling patterns that could be described as bands or punctate sites were 
542 C. RIBEIRO-CARVALHO ET AL.
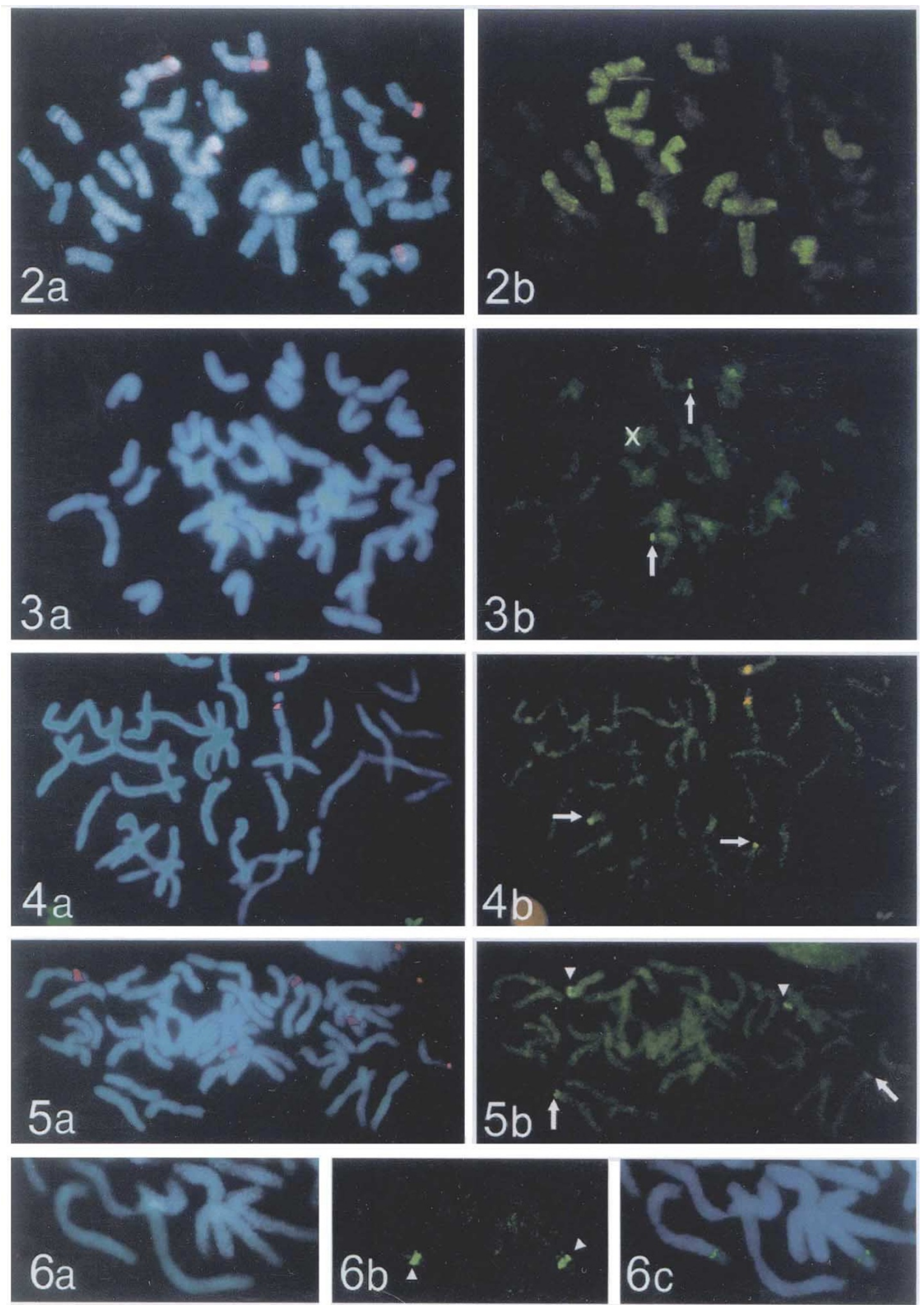

(c) The Genetical Society of Great Britain, Heredity, 78, 539-546. 
detected under any circumstances on wheat-origin chromosomes. Depending on the batch of probe used, the terminal heterochromatin on rye-origin chromosomes was labelled equally, slightly more weakly or slightly more brightly than the rest of the rye chromosomes.

In situ hybridization to wheats carrying a centromeric $1 \mathrm{BL}-1 \mathrm{RS}$ translocation, revealed the $1 \mathrm{R}$ chromosome arm by its bright fluorescence, whereas other chromosome arms showed only very weak signal (see Heslop-Harrison et al., 1991). DAPI staining revealed bright terminal bands on both of the $1 \mathrm{R}$ origin chromosome arms, and there were smaller DAPI-bright segments visible in wheatorigin chromosome arms.

\section{Barbela lines 56/92 and 38/119}

These two lines showed a small terminal segment on one pair of chromosomes with bright green fluorescence following in situ hybridization with rye total genomic as probe, indicating the presence of a wheat-rye translocation (Figs 3 and 4). In both lines, the segment was located on the short arm of a submetacentric chromosome, and occupied about 5 per cent of the chromosome. No clear differences were detected between the lines, although the data presented here are not conclusive. Two major NORs were detected by in situ hybridization with the rDNA probe on chromosomes that were identified as wheat chromosomes $1 \mathrm{~B}$ and $6 \mathrm{~B}$. Minor sites, presumably originating from wheat chromosomes 5D and 1A were usually revealed, but under the hybridization and detection (including photographic) conditions used, we would not expect to see smaller NORs as they would be below the threshold for visualization. No NOR was detected on translocated chromosomes.

\section{Barbela line 39/114}

Four chromosomes including labelled chromosome segments were detected. As in lines 38/119 and $56 / 92$, one submetacentric chromosome pair had a small (5 per cent of the chromosome) terminal labelled segment on the short arm (Fig. 5). Notably, the other pair of labelled segments were interstitial, occupied 3.5 per cent of the chromosome and were located 75 per cent of the length of the arm from the centromere on the long arm of a chromosome with unequal arms (arm ratio 1.6; Figs 5 and 6). Results from the rDNA probe showed that no major NOR was present on either translocated chromosome pair.

\section{Barbela lines 16/95 and 34/66}

No segments of wheat chromosomes were seen to label with the rye DNA probe, indicating that rye chromosome segments were either absent or too small to detect conclusively with the technique described.

\section{Discussion}

The in situ hybridization results using rye genomic DNA as a probe show that two of the five Barbela wheat lines examined carefully include a pair of wheat chromosomes with small, terminal, rye-origin chromosome segments, and another line includes chromosomes with both a terminal and intercalary pair of segments.

Fig. 2 A triticale root-tip metaphase (chromosomes stained blue with the fluorochrome DAPI, panel (a) showing 14 chromosomes of rye origin hybridizing strongly with rye genomic DNA probe (detected yellow-green), whereas only weak and uniformly diffuse cross-hybridization is seen to the 28 wheat-origin chromosomes, with no bands. Chromosomes in (a) also show the major sites of rDNA hybridization (red). X indicates stain precipitate.

Fig. 3 A root-tip metaphase from Barbela accession 56/92, with chromosomes stained blue with DAPI (a), showing one pair of chromosomes with terminal rye-origin chromosome segments, labelled yellow-green with genomic rye DNA probe (b) on the short arm of a wheat chromosome (arrows).

Fig. 4 A root-tip metaphase from Barbela accession 38/119, with chromosomes stained blue with DAPI (a), showing one pair of chromosomes with terminal tye-origin chromosome segments in a partial metaphase hybridizing with labelled genomic rye DNA (b; green bands; arrows). The major rDNA sites (red in (a)) are also detected by the rye genomic DNA (green in (b)).

Fig. 5 A root-tip metaphase from Barbela accession 39/114, with chromosomes stained blue with DAPI (a), showing one pair of chromosomes with terminal rye-origin chromosome segments (arrows), and another pair with intercalary rye-origin segments (arrowheads) labelled green with genomic rye DNA probe (b). The major rDNA sites are also shown (red in (a)). Fig. 6 A partial metaphase from a root-tip of Barbela accession 39/114, with chromosomes stained blue with DAPI (a), showing the two chromosomes with intercalary rye-origin segments (arrowheads) labelled green with genomic rye DNA (b, c). (c) Superimposition of the DAPI and genomic probe in situ hybridization results to show the location of the intercalary chromosome segment near the end of the long arm of a wheat-origin chromosome.

(c) The Genetical Society of Great Britain, Heredity, 78, 539-546. 
Control slides of triticale (Fig. 1) or a $1 \mathrm{~B}-1 \mathrm{R}$ wheat variety revealed no small labelled chromosome segments, intercalary or terminal, of the type seen in the Barbela lines. Some repetitive sequences, including, for example, tandemly repeated sequences such as the rDNA and some tandem and dispersed repetitive sequences including retrotransposons, are common between wheat and rye, and could result in some hybridization signal from rye genomic DNA probe on wheat chromosomes. The controls show that only cross-hybridization of rDNA is detectable, and none of the other sequences present in the probe we used revealed any wheat chromosome segments. Furthermore, the lack of detectable hybridization in two of the Barbela lines examined confirms that the hybridization seen in the other three lines is not simply a property of a wheat variety that has not been previously investigatedcaused, for example, by molecular amplification of a tandemly repeated DNA sequence that is homologous to a sequence in the rye probe.

No DAPI-positive heterochromatin is visible correlating with the rye chromosome segments in the Barbela lines, in contrast to the $1 \mathrm{~B}-1 \mathrm{R}$ controls where terminal DAPI bands are visible on the $1 R$ chromosome arm. Although the translocated terminal segments may arise from the long arms of rye chromosomes which do not carry terminal heterochromatin, it is known that some Portugese rye varieties do not have detectable C-bands (L. Amado \& W. Viegas, personal communication), and similar lines may have provided the source for introgressed chromatin in Barbela. The rye-origin probe would also hybridize to chromosome segments originating from other rye or closely related species, and we cannot rule out introgression of chromosome segments from such a species. Probing of rye genomic DNA to another rye species would be likely to label the chromosomes along their length, with gaps or regions of less hybridization (as with barley and wild Hordeum species; Anamthawat-Jonsson et al., 1993) which could not be seen on small introgressed segments as here. However, no wild rye or closely related species occur in the same region as Barbela, whereas fields of rye and Barbela are often adjacent, so, along with the phenotypic indications, rye is likely to be the source of the alien chromosome segments.

Rye chromosome introgression has been reported in numerous wheat cultivars (Zeller, 1973; Lukaszewski, 1990; Javornik et al., 1991). However, the pedigrees of these cultivars indicate that they arise from relatively few original wheat-rye crosses, and include a translocation of the short arm of $1 \mathrm{R}$ and long arm of 1B of wheat (Heslop-Harrison et al., 1991). They have been selected by breeders because of their disease tolerance and other factors coming from the 1RS chromosome arm (Carver \& Rayburn, 1994), although undesirable genes, such as those for proteins giving sticky dough, are also transferred. It has been widely suggested that use of smaller translocations would be useful to improve agronomic characters of wheat varieties, while maintaining the yield advantages (VillaReal et al., 1991). Considerable efforts are being put into obtaining wheat-alien recombinant chromosomes with small alien chromosome segments carrying useful characteristics, and few or no linked deleterious genes (Koebner \& Shepherd, 1986). Methods widely used include the nulli-5B or $P h$ mutant which enables pairing and recombination between homologous chromosomes (Miller et al., 1994) or X-irradiation (Mukai et al., 1993), followed by extensive backcrossing. Another wheat variety, Viking, also has a small terminal rye-origin chromosome segment which has been identified by in situ hybridization (Schlegel et al., 1993) and by marker loci on chromosome 5 of rye, translocated to chromosome 4 of wheat.

Pairing between alien and wheat chromosomes, even in the presence of the $P h$ gene, has been detected by in situ hybridization (Miller et al., 1994). This type of pairing probably gave rise to the recombinants detected here, and it is notable that the segment transferred is small. Whether the intercalary recombinant occurred at a single meiosis or at two meioses is unknown. It is traditional to grow Barbela wheat in mixtures with rye in the northern, inner region of Portugal where hard winters, acid soils and poor fertility conditions are prevalent. It is also known that dry and hot spring and summer conditions are favourable for wheat outcross hybridization. Such conditions are not infrequent in a Mediterranean climate as in Portugal. Spontaneous wheat-rye hybrids are referred to in literature and thousands of hybrids appeared at the Agriculture Experiment Station of Saratov in 1918 (Meister in Müntzing, 1974). Natural introgression of rye germplasm into Barbela could, therefore, occur from spontaneous wheat-rye hybridization followed by backcrosses to Barbela wheat.

It is now well accepted that genes in wheat, rye and other Triticeae cereals are clustered (HeslopHarrison, 1991; Lukaszewski, 1992; Gill et al., 1993). A high proportion of the genetic length of each chromosome is represented by small physical regions, and it is clear that this reflects the physical distribution of recombination sites along chromosomes. Hence the small rye chromosome segments

(C) The Genetical Society of Great Britain, Heredity, 78, 539-546. 
in Barbela, if representing gene-rich regions, may include many genes. This could be confirmed by mapping of the genes on the segment, and the lines might provide a valuable resource for cloning ryeorigin genes.

In situ hybridization is a labour-intensive screening method, but the results presented show that it is able to give definitive results about the presence and size of alien chromosome segments in unknown lines. The use of molecular markers for this type of study is more difficult as nothing is known about the molecular genetics of either the wheat or rye parent (and hence their RFLP patterns are unknown), nor are there suitable candidate markers for many of the agronomic performance characteristics present in the lines. The different positions and sizes of the rye segments in Barbela chromosomes seem to indicate that more than one wheat-rye hybridization event has happened. Nevertheless, the results show that landraces material may include lines of considerable interest to plant breeders, and emphasize the importance of the assessment and conservation of threatened genetic stocks. The landraces, primitive forms and wild species constitute a rich genetic resource (Tahir \& Ketata, 1993) which deserves careful evaluation and preservation for further improvement of wheats.

\section{Acknowledgements}

This work was supported by Project Barbela PDRITM no. 2, European Union PTP-AMICA project and the British Council.

\section{References}

ANAMTHAWAT-JÓNSSON, K., SCHWARZACHER, T., LEITCH, A. R., BENNETT, M. D. AND HESLOP-HARRISON, J. S. 1990. Discrimination between closely related Triticeae species using genomic DNA as a probe. Theor. Appl. Genet., 79, $721-728$.

ANAMTHAWAT-JÓNSSON, K., SCHWARZACHER, T. AND HESLOP-HARRISON, J. S. 1993. Behavior of parental genomes in the hybrid Hordeum vulgare $\times H$. bulbosum. J. Hered., 84, 78-82.

BERNARD, M. AND GUEDES-PINTO, H. 1983. Étude comparative de quelques cultivars de blé, seigle et triticale dans le Nord du Portugal. Productions de grain, de paille, de proteínes. Agronomie, 3, 691-700.

CARVER, B. F. AND RAYBURN, A. L. 1994. Comparison of related wheat stocks possessing $1 \mathrm{~B}$ or $1 \mathrm{RS} .1 \mathrm{BL}$ chromosomes: agronomic performance. Crop Sci., 34, 1505-1510.

CASTilho, A. 1954. Manual enciclopédico do Agricultor Portugues. Agricultura II Parte, Grupo I-Cereais. Gazeta das Aldeias, 2, 1393-1425.

c) The Genetical Society of Great Britain, Heredity, 78, 539-546.
COUTinho, A. X. P. 1884. Os fenos espontaneos e as palhas de trigo, em Portugal. Estudos Agronómicos. Imprensa Nacional, Lisboa.

GERLACH, w. L. AND BEDBoOK, J. R. 1979. Cloning and characterization of ribosomal RNA genes from wheat and barley. Nucl. Acids Res., 7, 1869-1885.

GlLL, K. S., GILL, B. S. AND ENDO, T. R. 1993. A chromosome region-specific mapping strategy reveals gene-rich telomeric ends in wheat. Chromosoma, 102, 374-381.

GUEDES-PINTO, H., PINTO-CARNIDE, O. AND CARNIDE, V. 1982. Dois anos de ensaios de adaptacao com Triticales em Tras-os-Montes. Melhoramento, 27, 1-89.

HESLOP-HARRISON, J. s. 1991. The molecular cytogenetics of plants. J.Cell Sci., 100, 15-21.

HESLOP-HARRISON, J. S., SCHWARZACHER, T., LEITCH, A. R., ANAMTHAWAT-JÓNSSON, K. AND BENNETT, M. D. 1988. A method of identifying DNA sequences in chromosomes of plants. European Patent Application Number 8828130.8. December 2.

HESLOP-HARRISON, J. S., LEITCH, A. R., SCHWARZACHER, T. AND ANAMTHAWAT-JóNSSON, K. 1990. Detection and characterization of $1 \mathrm{~B} / 1 \mathrm{R}$ translocations in hexaploid wheat. Heredity, 65, 385-392.

HESLOP-HARRISON, J. S., SCHWARZACHER, T., ANAMTHAWATJÓNSSON, K., LEITCH, A. R., SH1, M. AND LEITCH, I. J. 1991. In situ hybridization with automated chromosome denaturation. Technique, 3, 109-116.

JAVORNIK, B., SINKOVIC, T., VAPA, L., KOEBNER, R. M. D. AND ROGERS, w. J. 1991. A comparison of methods for identifying and surveying the presence of 1BL.1RS translocations in bread wheat. Euphytica, 54, 45-53.

KOEBNER, R. M. D. AND SHEPHERD, K. w. 1986. Controlled introgression to wheat of genes from rye chromosome arm 1RS by induction of allosyndesis. 1. Isolation of recombinants. Theor. Appl. Genet., 73, 197-208.

LAPA, J. 1. F. 1865. Memória sobre o estudo industrial e químico dos trigos Portugueses. Tipografia Academia, Lisboa.

LUKASZEWSKI, A. J. 1990. Frequency of 1RS.1AL and 1RS.1BL translocations in United States wheats. Crop Sci., 30, 1151-1153.

LUKASZEWSK1, A. J. 1992. A comparison of physical distribution of recombination in chromosome $1 \mathrm{R}$ in diploid rye and in hexaploid triticale. Theor. Appl. Genet., 83, 1048-1053.

MARCHENAY, P. AND LAGARDE, M. F. 1987. A la recherche des varietés locales de plantes cultivés. Bureau des Ressources Génétiques, Paris.

MEINKOTH, J. AND WAHL, G. 1984. Hybridization of nucleic acids immobilized on solid supports. Analyt. Biochem., 138, 267-284.

MILLER, T. E., READER, S. M. AND PURDIE, K. A. 1994. Determination of frequency of wheat-rye chromosome pairing in wheat $\times$ rye hybrids with and without chromosome 5B. Theor. Appl. Genet., 89, 255-258.

montelro, A. C. 1935. Trigos Portugueses (Estudo da sua distributiçao no país). Boletim no. $17-$ Série $A$ de Estaçao Agrária Central, da Divisao, Ensaio de Sementes 
e Melhoramento das Plants. Direç̧ao Geral dos Serviços Agrícolas, Ministério da Agricultura, Lisboa.

MUKAI, Y., FRIEBE, J. H., YAMAMOTO, M. AND GILL, B. S. 1993. Molecular cytogenetic analysis of radiationinduced wheat-rye terminal and intercalary chromosomal translocation and detection of rye chromatin specifying resistance to Hessian fly. Chromosoma, 102, $88-95$.

MüNTZING, A. 1974. Historical review of the development of Triticale. In: MacIntyre, R. and Campbell, M. (eds) Triticale: Proceedings of an International Symposium, pp. 13-30. International Development Research Centre, Ottawa.

SAMBROOK, J., FRITSCH, E. F. AND MANIATIS, T. 1990. Molecular Cloning: A Laboratory Manual, 2nd edn. Cold Spring Harbor Press, New York.

SCHLEGEL, R., KYNAST, R., SCHWARZACHER, T., RÖMHELD, V. AND WALTER, A. 1993. Mapping of genes for copper efficiency in rye and the relationship between copper and iron efficiency. Plant Soil, 154, 61-65.

SCHMIDT, T. AND HESLOP-HARRISON, J. S. 1996. High resolution mapping of repetitive DNA by in situ hybridization: Molecular and chromosomal features of prominent dispersed and discretely localized DNA families from the wild beet species Beta procumbens. Plant Mol. Biol., 30, 1099-1114.

SCHWARZACHER, T., ANAMTHAWAT-JÓNSSON, K., HARRISON, G. E., ISLAM, A. K. M. R., JIA, J. Z., KING, 1. P. ET AL. 1992. Genomic in situ hybridization to identify alien chromo- somes and chromosome segments in wheat. Theor. Appl. Genet., 84, 778-786.

SCHWARZACHER, T., LEITCH, A. R. AND HESLOP-HARRISON, J. s. 1994. DNA-DNA in situ hybridization-methods for light microscopy. In: Harris, N. and Oparka, K.J. (eds) Plant Cell Biology: A Practical Approach, pp. 127-155. IRL/Oxford University Press, Oxford.

SILVA, J. P., REBOREDO, F., GUEDES-PINTO, H. AND MELLOSAMPAYO, T. 1991. Barbela, a bread wheat cultivar tolerant to de aluminum. Broteria-Genetica, XII (LXXXVII), 65-68.

TAHIR, M. AND KETATA, H. 1993. Use of landraces, primitive forms and wild species for the development of winter and facultative durum wheat germplasm. In: Damania, A. B. (ed.) Biodiversity and Wheat Improvement, pp. 341-351. John Wiley and Sons, Chichester.

vasConcelos, J. c. 1933. Trigos Portugueses ou de há muito cultivados no País (subsídios para o seu estudo botanico). Boletim de Agricultura Ano I, (1-2) 1 série, Lisboa, Direcçao Geral de Acçao Social Agrária.

VILLAREAL, R. L., RAJARAM, S., MUJEeb-KAZI, A. AND DEL TORO, E. 1991. The effect of chromosome 1B/1R translocation on the yield potential of certain spring wheats (T. aestivum L.). Pl. Breed., 106, 77-81.

ZELLER, F. J 1973. 1B/1R wheat-rye chromosome substitutions and translocations. In: Sears, E. R. and Sears, L. M. S. Proc. 4th Int. Wheat Genet. Symp., pp. 209-222. Missouri Agric. Expl. Stn., Columbia, OH. 